\title{
IZBOR VRSTA DRVEĆA ZA SUPSTITUCIJU NASADA TOPOLA UZ RIJEKU DRAVU KOD OSIJEKA
}

\section{SELECTION OF TREE SPECIES FOR THE SUBSTITUTION OF POPLAR PLANTATIONS ALONG THE RIVER DRAVA NEAR OSIJEK}

\author{
Igor ANIĆ1, Stjepan MIKAC², Mladen OGNJENOVIĆ3
}

\begin{abstract}
Sažetak
U radu su prikazani rezultati istraživanja preživljenja i rasta nekih vrsta drveća kojima bi se u slučaju potrebe mogla obaviti zamjena topola u nasadima. Pokus je postavljen na području Šumarije Valpovo, u Gospodarskoj jedinici Valpovačke podravske šume, šumski predjel Topolje, odsjek 23a. Taj lokalitet predstavlja tipičan primjer slabog uspijevanja i odumiranja nasada topola, čak i nakon višekratnih popunjavanja sadnicama topole i njege. Pokus je postavljen po shemi slučajno-bloknog rasporeda, sa šest tretiranja u četiri bloka. Tretirani su sljedeći sastojinski oblici: A - hrast lužnjak, B - poljski jasen, C - bagrem, D - hrast lužnjak s običnim grabom, E - divlja trešnja s poljskim jasenom i F - divlja trešnja s običnim grabom. Pokus je postavljen 18. studenog 2009. godine. Preživljenje biljaka je utvrđeno svake godine tijekom petogodišnjeg praćenja pokusa. Tijekom zime 2015. godine izmjerene su visine svih stabala te je određen prostorni položaj živih i odumrlih jedinki po plohicama. S obzirom na preživljenje i visine kao indikatore rasta i razvoja biljaka, najbolje su rezultate pokazali redom obični bagrem, poljski jasen i hrast lužnjak. Najlošije rezultate postigli su divlja trešnja i obični grab. S obzirom na mikroreljef, najbolje preživljenje je pokazao obični bagrem koji podjednako dobro raste u nizi i na gredi. Poljski jasen i hrast lužnjak bolje preživljenje imaju u nizi. Divlja trešnja i obični grab imaju općenito loše preživljenje, neovisno o mikroreljefu. Rezultati istraživanja pokazali su kako je nasade topola u promijenjenim stanišnim prilikama nakon višekratnih ophodnji moguće zamijeniti sa sastojinom koja svojim sastojinskim oblikom odgovara terminalnoj šumskoj zajednici istraživanoga podučja - veza i poljskog jasena s hrastom lužnjakom (Fraxino-Ulmetum laevis Slavnić 1952). Postupku treba prethoditi izrada detaljnog šumskouzgojnog plana, koji bi između ostalog definirao područja niza i greda u određenom odjelu. Nize i vlažne grede treba prepustiti poljskom jasenu koji je pokazao vrlo dobre rezultate u pokusu. Hrast lužnjak je pokazao zavidnu stabilnost i vitalitet, pa ga treba upotrebljavati u smjesi s poljskim jasenom. Obični bagrem preporuča se za najsuše lokalitete s pjeskovitim tlima koja su naglo ostala bez podzemne i poplavne vode, na kojima nema uvjeta za nastavak uzgajanja topola.
\end{abstract}

KLJUČNE RIJEČI: topole, hrast lužnjak, poljski jasen, obični bagrem, analiza varijance

\section{UVOD}

\section{INTRODUCTION}

Prema izvješću Hrvatskog povjerenstva za topolu (2015.) u Republici Hrvatskoj imamo 24.127 ha topolovih šuma, od čega je 12.858 ha ili $53 \%$ prirodnih sastojina, a 11.269 ha ili $45 \%$ su umjetno osnovani nasadi u koje ubrajamo šumske kulture, intenzivne šumske kulture i šumske plantaže. $\mathrm{Na}$ području kojim gospodari Uprava šuma podružnica Osi-

\footnotetext{
${ }^{1}$ Akademik Igor Anić, Sveučilište u Zagrebu, Šumarski fakultet, Svetošimunska 25, HR - 10000 Zagreb, anic@sumfak.hr

${ }^{2}$ Doc. dr. sc. Stjepan Mikac, Šumarski fakultet, Svetošimunska 25, HR - 10000 Zagreb, mikac@sumfak.hr

${ }^{3}$ Mladen Ognjenović, mag. ing. silv., Hrvatski šumarski institut, HR - 10450 Jastrebarsko, mladeno@sumins.hr
} 
jek, uz rijeke Dravu i Dunav, topolove šume rastu na 10.878 ha ili $45 \%$ njihove ukupne površine. Prirodne sastojine se prostiru na 3.678 ha ili $34 \%$ površine, a umjetno osnovani nasadi na 7.199 ha ili $66 \%$ površine. Osim velike površine, posebnost uzgajanja topola kod Osijeka su duga tradicija od 1920. godine i činjenica kako je riječ o temeljnoj djelatnosti te glavnome izvoru prihoda šumarstva. Zbog svega toga osječko se područje s pravom može nazvati središtem hrvatskoga topolarstva, pa problemi u uspijevanju topola mogu imati teške šumskogospodarske posljedice.

Nasadi topola na tom su području nastajali na dva načina (Anić i Kajba, 2015.):

a) Sječom prirodnih sastojina ritskih šuma i osnivanjem nasada topola na njihovu mjestu. Razlozi ovakvom postupanju bili su gospodarski i ekološko-biološki. U prvom slučaju radilo se o želji za povećanjem količine proizvodnje drvne tvari. U drugom slučaju opravdanje je pronađeno u poteškoćama prirodne obnove zbog neusklađenosti plavljenja, taloženja nanosa, fruktifikacije i naplodnje te u niskoj kakvoći sastojina nastalih prirodnom vegetativnom obnovom (Sikora, 1995., Antunović, 1995.).

b) Pošumljavanjem novootkupljenih poljoprivrednih i pašnjačkih površina koje su obično udaljene od rijeke i nasipom zaštićene od poplave. Sa šumarskoga gledišta to su bila neobrasla proizvodna šumska zemljišta, pa je odluka o topoli kao pionirskoj vrsti drveća za pošumljavanje bila ispravna. To uostalom pokazuju podaci o strukturi, proi- zvodnji i prirastu topolovih nasada iz kojih je razvidno kako je uspjeh osnivanja i uspijevanja prvih generacija bio zadovoljavajući (usp. osnove gospodarenja G. j. Valpovačke podravske šume za razdoblja 1957. - 1966., 1967. - 1977., 1974. - 1983., 1984. - 1993., 1994. - 2003., 2004. - 2013. i G. j. Osiječke podravske šume za razdoblja 1967. - 1976., 1977. - 1986., 1987. - 1996., 1997. - 2006., 2007. - 2016.).

Tehnologija osnivanja i njege nasada topola bila je definirana od samih početaka topolarstva u nas (usp. Španović, 1931., Podhorski, 1951.), a razvijana je do danas (usp. Dekanić, 1979., Antunović, 1995., Sikora, 1995., 1996., Matić i dr., 2005.). Nasadi su uzgajani u ophodnjama 20 - 30 godina.

Činjenica je kako se na nekim lokalitetima toga područja topola uzgaja već u trećoj ophodnji. U posljednjem desetljeću pojavili su se problemi uspijevanja takvih nasada, posebice u valpovačkoj i zapadnoj osječkoj Podravini. Došlo je do pada vitaliteta i pojačanog odumiranja stabala. Pojava je uključivala čitave mlade nasade, posebice one koji su osnovani kao treća generacija na istom staništu. Otvorila su se pitanja o uzrocima tih pojava, metodama prilagodbe topolarstva u promijenjenim ekološkim prilikama i izboru drugih vrsta drveća koje bi bolje uspijevale u novim okolnostima.

U ovom su radu prikazani rezultati istraživanja uspijevanja nekih vrsta drveća kojima bi se u slučaju potrebe mogla obaviti zamjena ili supstitucija topola u nasadima.

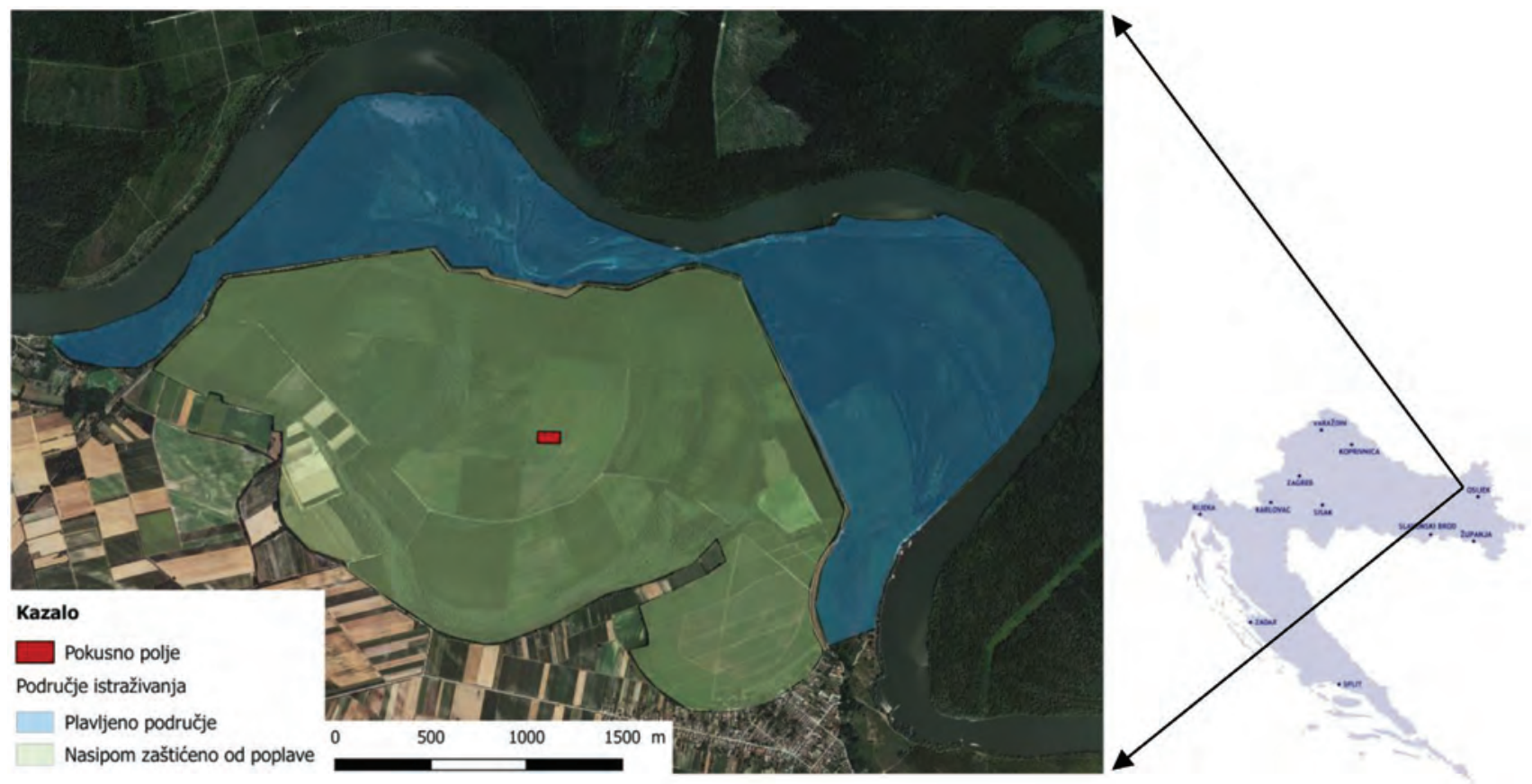

Slika 1. Područje istraživanja i položaj pokusnog polja. Zelenom bojom prikazano je područje koje je nasipom zaštićeno od poplave, a plavom bojom područje koje je redovito poplavljeno.

Figure 1 Study area and the position of the experimental plot. The area protected from floods by a dyke is marked in green, and the regularly flooded area is marked in blue. 
Tablica 1. Shema pokusa sa slučajno-bloknim rasporedom tretiranja Table 1 Scheme of trial with randomized block treatment

\begin{tabular}{|c|c|c|c|c|}
\hline $\begin{array}{c}\text { Blokovi - Blocks } \\
\text { Tretiranja - Treatments }\end{array}$ & 1 & 2 & 3 & 4 \\
\hline$A$ & $\begin{array}{c}\text { hrast lužnjak } \\
\text { pedunculate oak }\end{array}$ & $\begin{array}{l}\text { obični bagrem } \\
\text { black locust }\end{array}$ & $\begin{array}{c}\text { poljski jasen } \\
\text { narrow-leaved ash }\end{array}$ & $\begin{array}{l}\text { divlja trešnja i obični grab } \\
\text { willd cherry and common } \\
\text { hornbeam }\end{array}$ \\
\hline B & $\begin{array}{c}\text { poljski jasen } \\
\text { narrow-leaved ash }\end{array}$ & $\begin{array}{c}\text { divlja trešnja i poljski jasen } \\
\text { willd cherry and narrow-lea- } \\
\text { ved ash }\end{array}$ & $\begin{array}{c}\text { hrast lužnjak i obični grab } \\
\text { pedunculate oak and common } \\
\text { hornbeam }\end{array}$ & $\begin{array}{c}\text { obični bagrem } \\
\text { black locust }\end{array}$ \\
\hline C & $\begin{array}{l}\text { obični bagrem } \\
\text { black locust }\end{array}$ & $\begin{array}{c}\text { hrast lužnjak } \\
\text { pedunculate oak }\end{array}$ & $\begin{array}{l}\text { divlja trešnja i poljski jasen } \\
\text { willd cherry and narrow-lea- } \\
\text { ved ash }\end{array}$ & $\begin{array}{c}\text { hrast lužnjak i obični grab } \\
\text { pedunculate oak and common } \\
\text { hornbeam }\end{array}$ \\
\hline$D$ & $\begin{array}{c}\text { hrast lužnjak i obični grab } \\
\text { pedunculate oak and common } \\
\text { hornbeam }\end{array}$ & $\begin{array}{c}\text { divlja trešnja i obični grab } \\
\text { willd cherry and common } \\
\text { hornbeam }\end{array}$ & $\begin{array}{l}\text { obični bagrem } \\
\text { black locust }\end{array}$ & $\begin{array}{c}\text { hrast lužnjak } \\
\text { pedunculate oak }\end{array}$ \\
\hline $\mathrm{E}$ & $\begin{array}{c}\text { divlja trešnja i poljski jasen } \\
\text { willd cherry and narrow-lea- } \\
\text { ved ash }\end{array}$ & $\begin{array}{c}\text { poljski jasen } \\
\text { narrow-leaved ash }\end{array}$ & $\begin{array}{l}\text { divlja trešnja i obični grab } \\
\text { willd cherry and common } \\
\text { hornbeam }\end{array}$ & $\begin{array}{c}\text { divlja trešnja i poljski jasen } \\
\text { willd cherry and narrow-lea- } \\
\text { ved ash }\end{array}$ \\
\hline$F$ & $\begin{array}{c}\text { divlja trešnja i obični grab } \\
\text { willd cherry and common } \\
\text { hornbeam }\end{array}$ & $\begin{array}{c}\text { hrast lužnjak i obični grab } \\
\text { pedunculate oak and common } \\
\text { hornbeam }\end{array}$ & $\begin{array}{c}\text { hrast lužnjak } \\
\text { pedunculate oak }\end{array}$ & $\begin{array}{c}\text { poljski jasen } \\
\text { narrow-leaved ash }\end{array}$ \\
\hline
\end{tabular}

\section{MATERIJAL I METODE}

\section{MATERIAL AND METHODS}

Pokus je postavljen na području Šumarije Valpovo, u Gospodarskoj jedinici Valpovačke podravske šume, šumski predjel Topolje, odsjek 23a. Taj lokalitet predstavlja tipičan primjer slabog uspijevanja i odumiranja sastojina topola, čak i nakon višekratnih popunjavanja sadnicama topole i njege. Stara sastojina topole je posječena 2000. godine, a godinu dana kasnije obavljena je sadnja topolovih sadnica. Novoosnovana sastojina, zbog izraženog odumiranja, nije dočekala kraj ophodnje.

Šumski predjel Topolje nalazi se na aluvijalnoj terasi nastaloj meandriranjem rijeke Drave. Reljef je izbrazdan pojasima aluvijalnih mikrouzvisina - greda i mikroudubina niza i nekadašnjih mrtvaja. Pojasevi se protežu usporedno s tokom rijeke Drave. Pokus se nalazi u središnjem dijelu šumskog predjela koji je nasipom branjen od poplave, na nadmorskim visinama 88 - 89 metara (Slika 1).

Prosječna godišnja temperatura zraka na meteorološkoj postaji Valpovo, za razdoblje 1983. - 2010., je $11,2^{\circ} \mathrm{C}$, a prosječna temperatura zraka u vegetacijskom razdoblju iznosi $18,0^{\circ} \mathrm{C}$. Najniža srednja mjesečna temperatura zraka je $0,1^{\circ} \mathrm{C}$ u mjesecu siječnju, dok je najviša $21,8^{\circ} \mathrm{C}$ u mjesecu srpnju. Prosječna godišnja količina oborine iznosi $709 \mathrm{~mm}$. Tijekom vegetacijskog razdoblja padne $400 \mathrm{~mm}$ ili 56 \% godišnje količine oborina. Kasni proljetni mrazevi nastaju krajem travnja, a izuzetno i u svibnju. Rani jesenski mrazevi počinju u listopadu, a izuzetno ih ima i krajem rujna. Prosječni godišnji broj dana s mrazom iznosi 4 dana. Prosječna godišnja relativna vlažnost zraka iznosi $78 \%$, a relativna vlažnost zraka u vegetacijskom periodu iznosi $75 \%$.
Pokus je postavljen po shemi slučajno-bloknog rasporeda, sa šest tretiranja u četiri bloka. Tretiranja su sljedeći sastojinski oblici: A - hrast lužnjak, B - poljski jasen, C - bagrem, $\mathrm{D}$ - hrast lužnjak s običnim grabom, $\mathrm{E}$ - divlja trešnja s poljskim jasenom i $\mathrm{F}$ - divlja trešnja s običnim grabom (Tablica 1). Dob sadnica hrasta lužnjaka prilikom uspostavljanja pokusa je bila $2+0$, dok je dob sadnica ostalih vrsta iznosila $1+0$. Sadnice su posađene u pravokutnom rasporedu, $u$ razmacima navedenima u Tablici 2. Kod mješovite sadnje dvije vrste drveća, sadnice jedne vrste su posađene u jednome redu, a druge vrste u drugome redu. Redovi se nižu naizmjenično. Zaštitni pojas oko pokusa osnovan je s dva reda sadnica poljskog jasena. Površina svake plohice iznosi $25,35 \mathrm{~m}$ x 6,88 m ili 174,41 $\mathrm{m}^{2}$. Ukupna površina pokusa, bez zaštitnog pojasa, iznosi 101,40 m x 41,30 m ili 0,42 ha. Pokus je ograđen armaturnom mrežom. Jugoistočni ugao pokusa ima koordinate $40^{\circ} 40^{\prime} 33,54^{\prime \prime}$ S i $18^{\circ} 28^{\prime} 04,47^{\prime \prime}$ I.

Pokus je postavljen 18. studenog 2009. godine. Prva izmjera u kojoj se ustanovilo preživljenje biljaka je obavljena pri kraju vegetacije 2010. godine. U jesen 2011. godine, nakon druge vegetacije od postavljanja pokusa, ustanovljeno je preživljenje biljaka i izmjerene su njihove visine. Početkom treće vegetacije, u travnju 2012. godine, pokus je bio izložen mrazu. Sve biljke osim bagrema tom su prilikom odumrle, pa se obavio zahvat čepovanja. U jesen 2013. godine izmjereno je preživljenje biljaka i njihove visine, a postupak se ponovio u jesen 2014. godine. Tijekom zime 2015. godine izmjerene su visine svih stabala te je određen prostorni položaj živih i odumrlih jedinki po plohicama. Za izmjeru visina korištena je mjerna vrpca, a u slučaju viših stabala mjerna letva. Mjerenje visina je obavljeno s preciznošću od jednog centimetra. 
Tablica 2. Prostorni raspored biljaka i gustoća sadnje po tretiranjima Table 2 Spatial plant arrangement and planting density per treatment

\begin{tabular}{|c|c|c|c|c|}
\hline \multicolumn{2}{|c|}{ Tretiranje - Treatments } & \multirow{2}{*}{$\begin{array}{c}\text { Razmak između redova - } \\
\text { Spacing between rows } \\
\text { m } \\
2,60\end{array}$} & \multirow{2}{*}{$\begin{array}{c}\text { Razmak unutar reda - Spa- } \\
\text { cing within the rows } \\
\text { kom. - pcs } \\
0,70\end{array}$} & \multirow{2}{*}{$\begin{array}{l}\text { Broj biljaka na plohici - } \\
\text { Number of plants per } \\
\text { sampling plot } \\
100\end{array}$} \\
\hline A & $\begin{array}{l}\text { hrast lužnjak } \\
\text { pedunculate oak }\end{array}$ & & & \\
\hline B & $\begin{array}{l}\text { poljski jasen } \\
\text { narrow-leaved ash }\end{array}$ & 2,60 & 0,70 & 100 \\
\hline C & $\begin{array}{l}\text { obični bagrem } \\
\text { black locust }\end{array}$ & 2,60 & 1,40 & 50 \\
\hline D & $\begin{array}{l}\text { hrast lužnjak i obični grab* } \\
\text { pedunculate oak and common hornbeam* }\end{array}$ & 2,60 & $0,70 / 0,70$ & $50 / 50$ \\
\hline E & $\begin{array}{l}\text { divlja trešnja i poljski jasen* } \\
\text { willd cherry and narrow-leaved ash* }\end{array}$ & 2,60 & $1,40 / 0,70$ & $25 / 50$ \\
\hline $\mathrm{F}$ & $\begin{array}{l}\text { divlja trešnja i obični grab* } \\
\text { willd cherry and common hornbeam* }\end{array}$ & 2,60 & $1,40 / 0,70$ & $25 / 50$ \\
\hline
\end{tabular}

* mješovita sadnja u redove, jedna vrsta u jednome redu, nizanje redova naizmjenično

* mixed planting in rows, one species in one row, alternate row arrangement

Preživljenje biljaka je utvrđeno svake godine tijekom petogodišnjeg praćenja pokusa, na svakoj plohici, brojanjem odumrlih biljaka tijekom godine i iz razlike između broja živih biljaka između dvije izmjere. Rezultati su prikazani po vrstama drveća. Prosječni godišnji mortalitet biljaka izračunat je iz razlike između broja živih biljaka zatečenih tijekom zime 2015. godine i početnog broja biljaka u doba osnutka pokusa u jesen 2009. godine.

Statistička obrada podataka provedena je u statističkom programu Past 3.0 (Hammer, 2001.) i Microsoft Office Excel 2010. Izračunate su osnovne deskriptivne vrijednosti visina po vrstama drveća i plohicama iste vrste drveća. Kako bi utvrdili postoji li statistički značajna razlika u visinama između pojedinih vrsta drveća proveli smo jednostruku analizu varijance (One-way ANOVA) s Tukey HSD post-hoc testom (Tukey, 1949.). Osim po vrstama drveća, napravljena je analiza visina po blokovima, s ciljem da se ustanovi je li neka vrsta drveća pokazala značajno bolji ili lošiji visinski rast na određenom dijelu pokusa. Zaključak u oba slučaja je donešen na temelju dobivene $\mathrm{p}$-vrijednosti uz zadanu razinu značajnosti $\alpha=95 \%$. U slučaju da pretpostavka homogenosti varijance nije zadovoljena za izračun $\mathrm{F}$ i p vrijednosti korišten je Welch-ov test (Welch, 1951.).

\section{REZULTATI}

\section{RESULTS}

\section{Preživljenje po vrstama drveća - Survival per tree species}

Rezultati analize preživljenja i mortaliteta biljaka prikazani su po vrstama drveća i godinama praćenja (Slika 2). Najmanje preživljenje nakon pet godina pokazao je obični grab u iznosu od 23,25\%. Najbolje preživljenje utvrđeno je za obični bagrem $97,50 \%$, a slijede poljski jasen $90,88 \%$ i hrast lužnjak $82,88 \%$. Preživljenje divlje trešnje je $54,00 \%$. Tu treba napomenuti da je tijekom posljednje izmjere na terenu zamijećen veći broj suhih trešanja koje su potjerale nove izbojke.

I dok je preživljenje bagrema na visokoj razini kroz čitavo promatrano razdoblje, preživljenje hrasta lužnjaka je na dobroj razini, ali s trendom opadanja kroz prve četiri godine. Obrnuti trend ima poljski jasen kojemu je preživljenje, nakon obavljenog čepovanja, naglo poraslo i sada je na dru-

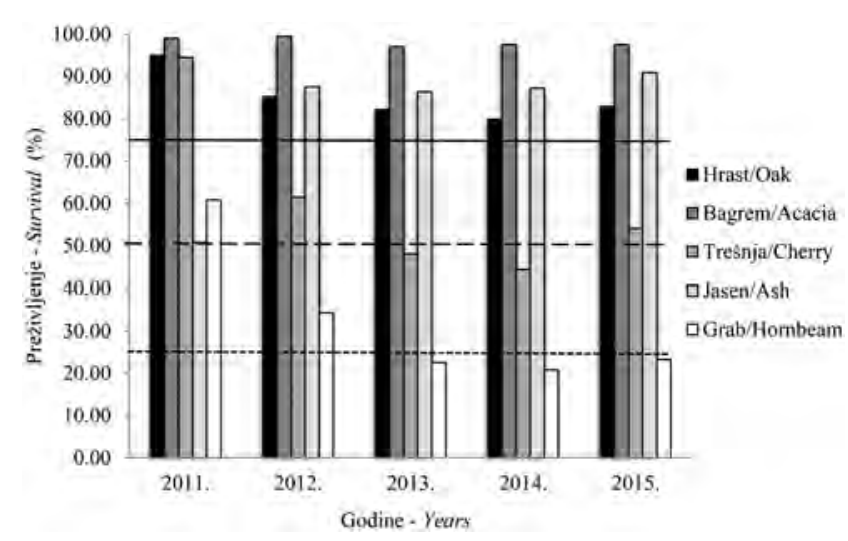

Slika 2. Postotak preživljenja prema vrstama drveća i godinama mjerenja. Punom crtom je označena vrlo dobra granica preživljenja $\langle P\rangle$ $75 \%)$, crtkanom crtom je označena osrednja granica preživljenja $(P \approx 50 \%)$, a točkastom crtom je označena loša granica preživljenja $(\mathrm{P}<25 \%)$

Figure 2 Survival percentage per tree species and year of measurement. Very good survival boundary ( $S>75 \%$ ) is marked with a full line, medium survival boundary $(S \approx 50 \%)$, is marked with a dashed line, and poor survival boundary $(S<25 \%)$ is marked with a dotted line. 
Tablica 3. Deskriptvna statistika za visine (cm) po vrstama drveća

Table 3 Descriptive statistics for heights $(\mathrm{cm})$ per tree species

$\begin{array}{lccccc}\text { Vrste drveća - Tree } & \begin{array}{c}\text { Hrast lužnjak } \\ \text { species }\end{array} & \begin{array}{c}\text { Poljski jasen } \\ \text { Pedunculate oak }\end{array} & \begin{array}{c}\text { Obični bagrem } \\ \text { Narrow-leaved ash }\end{array} & \begin{array}{c}\text { Divlja trešnja } \\ \text { Willd cherry }\end{array} & \begin{array}{c}\text { Obični grab } \\ \text { Common hornbeam }\end{array} \\ \text { Varijable - Variable } & 505 & 544 & 195 & 108 & 93 \\ \text { N } & 27,0 & 23,0 & 81,0 & 30,0 & 34,0 \\ \text { Min. } & 290,0 & 390,0 & 610,0 & 450,0 & 240,0 \\ \text { Max. } & 96,5 & 110,0 & 345,8 & 152,5 & 112,8 \\ \text { Mean } & 1,7 & 2,3 & 8,5 & 6,0 & 5,3 \\ \text { Std. error } & 1531,6 & 2928,7 & 13991,2 & 3897,7 & 2637,0 \\ \text { Variance } & 39,1 & 54,1 & 118,3 & 62,4 & 51,4 \\ \text { Std. dev. } & 90,0 & 100,0 & 360,0 & 155,0 & 105,0\end{array}$

Tablica 4. Rezultati jednostruke analize varijance s obzirom na utvrđene visine biljaka između pojedinih vrsta drveća Table 4 Results of one-way analysis of variance with regard to the recorded plant heights among particular tree species

\begin{tabular}{|c|c|c|c|c|c|}
\hline & $\begin{array}{l}\text { Suma Kvadrata } \\
\text { SS }\end{array}$ & $\begin{array}{l}\text { Stupnjevi slobode } \\
\quad d f\end{array}$ & $\begin{array}{l}\text { Sredina kvadrata } \\
\text { MS }\end{array}$ & $\begin{array}{l}\text { F - vrijednost } \\
\text { F-value }\end{array}$ & $\begin{array}{l}p \text { - vrijednost } \\
p \text {-value }\end{array}$ \\
\hline $\begin{array}{l}\text { Između grupa } \\
\text { Between groups }\end{array}$ & $9,75 \mathrm{E}+06$ & 4 & $2,45 E+06$ & 613,9 & $3,46 \mathrm{E}-309$ \\
\hline $\begin{array}{l}\text { Unutar grupa } \\
\text { Within groups }\end{array}$ & $5,73 E+06$ & 1439 & 3985,15 & & \\
\hline $\begin{array}{l}\text { Ukupno } \\
\text { Total }\end{array}$ & $1,55 \mathrm{E}+07$ & 1443 & & & \\
\hline $\begin{array}{l}\omega^{2} \\
\omega^{2}\end{array}$ & 0,6293 & & & & \\
\hline \multicolumn{3}{|c|}{$\begin{array}{l}\text { Levenov test homogenosti varijance iz aritmetičkih sredina } \\
\text { Levene's test for homogeneity of variance, from means }\end{array}$} & \multicolumn{3}{|c|}{ p: $1,095 \mathrm{E}-88$} \\
\hline \multicolumn{3}{|c|}{$\begin{array}{l}\text { Levenov test iz mediana } \\
\text { Levene's test, from medians }\end{array}$} & \multicolumn{3}{|c|}{ p: $1,643 \mathrm{E}-83$} \\
\hline \multicolumn{3}{|c|}{$\begin{array}{l}\text { Welch F test u slučaju nejednakih varijanci } \\
\text { Welch F test in the case of unequal variances }\end{array}$} & \multicolumn{3}{|c|}{$F=219,9 \quad d f=339,5 \quad p=1,171 E-91$} \\
\hline
\end{tabular}

gom mjestu, iza običnog bagrema. Najveći pad preživljenja zabilježen je kod divlje trešnje.

Najviše vrijednosti preživljenja zabilježene su na plohicama na kojima su posađeni obični bagrem (A2, B4, C1, D3), poljski jasen s divljom trešnjom (B2, C3, E1) i samostalno (E2) te hrast lužnjak samostalno (A1, F3). Divlja trešnja i obični grab na većini površine pokusa imaju loše preživljenje. Poljski jasen pokazuje stabilnost na cijelom pokusu, neovisno o mikroreljefu. Hrast lužnjak najbolje preživljava na plohicama A1, C2 i F3 koje se većim dijelom nalaze u nizi. Plohice na kojima je posađen hrast lužnjak s običnim grabom (B3, C4) i i hrast lužnjak samostalno (D4), u kojima je naglašena izmjena niza i greda na maloj udaljenosti, pokazuju slabije rezultate.

\section{Visine po vrstama drveća - Heights per tree species}

Osnovne deskriptivne vrijednosti postignutih visina po vrstama drveća u 2015. godini su prikazane u Tablici 3. Najveću prosječnu visinu postigao je obični bagrem, a slijede redom divlja trešnja, poljski jasen, obični grab i hrast lužnjak. Podsjećamo kako su sve biljke podvrgnute čepovanju nakon proljetnoga mraza u travnju 2012. godine, osim bagrema koji je preživio mraz. Tako su visine za sve vrste drveća, osim bagrema, ostvarene tijekom četiri vegetacijska razdoblja (2012. - 2015.). U slučaju bagrema riječ je o šest vegetacijskih razdoblja (2010. - 2015.). Iz toga slijedi kako je prosječni visinski prirast u promatranim razdobljima za hrast lužnjak iznosio $24,2 \mathrm{~cm}$, obični grab $26,8 \mathrm{~cm}$, poljski jasen 27,6 cm, divlju trešnju 38,1 cm, a za bagrem $57,6 \mathrm{~cm}$.

U Tablici 4. prikazani su rezultati analize varijance pomoću koje su uspoređene visine po vrstama drveća. Većina vrsta statistički se značajno razlikuju prema visinama izmjerenima u 2015. godini (Tablica 5). Statistički značajna razlika nije utvrđena između hrasta i jasena, hrasta i graba te između jasena i graba.

Osim prema vrstama drveća, napravljena je analiza visina i prema plohicama u blokovima s ciljem ispitivanja da li je neka vrsta drveća pokazala značajno bolji ili lošiji visinski 
Tablica 5. Rezultati Tukey HSD post hoc testa $(p<0,05)$ s obzirom na utvrđene visine biljaka između pojedinih vrsta drveća. Masno otisnuta polja predstavljaju statistički značajne razlike u visinama između pojedinih vrsta drveća.

Table 5 Results of Tukey HSD post hoc test $(p<0,05)$ with regard to the recorded plant heights among individual tree species. Bold areas represent statistically significant differences in the heights among individual tree species.

\begin{tabular}{|c|c|c|c|c|c|}
\hline $\begin{array}{l}\text { Vrsta drveća } \\
\text { Tree species }\end{array}$ & $\begin{array}{c}\text { Hrast lužnjak } \\
\text { Pedunculate oak }\end{array}$ & $\begin{array}{c}\text { Poljski jasen } \\
\text { Narrow-leaved ash }\end{array}$ & $\begin{array}{l}\text { Obični bagrem } \\
\text { Black locust }\end{array}$ & $\begin{array}{l}\text { Divlja trešnja } \\
\text { Willd cherry }\end{array}$ & $\begin{array}{c}\text { Obični grab } \\
\text { Common hornbeam }\end{array}$ \\
\hline Hrast lužnjak - Pedunculate oak & & 0,2785 & $1,72 \mathrm{E}-05$ & 1,72E-05 & 0,117 \\
\hline Poljski jasen - Narrow-leaved ash & & & $1,72 \mathrm{E}-05$ & $1,73 \mathrm{E}-05$ & 0,9936 \\
\hline Obični bagrem - Black locust & & & & $1,72 \mathrm{E}-05$ & $1,72 \mathrm{E}-05$ \\
\hline Divlja trešnja - Willd cherry & & & & & $1,73 \mathrm{E}-05$ \\
\hline
\end{tabular}

rast na određenom dijelu pokusnog polja. Rezultati deskriptivne statističke analize prikazani su u Tablici 6. Testiranja su provedena jednostrukom analizom varijance (Tablica 7).
Značajne razlike ustanovljene su kod hrasta lužnjaka, običnog bagrema i poljskog jasena, dok kod divlje trešnje i običnoga graba nije bilo razlika (Tablica 8 ).

Tablica 6. Deskriptivna statistika za visine $(\mathrm{cm})$ po vrstama drveća i plohicama

Table 6 Descriptive statistics for heights $(\mathrm{cm})$ per tree species and subplots

\begin{tabular}{|c|c|c|c|c|c|c|c|c|c|}
\hline \multirow{2}{*}{$\begin{array}{l}\text { Vrsta drveća } \\
\text { Tree species }\end{array}$} & \multirow{2}{*}{$\begin{array}{l}\text { Plohica } \\
\text { Subplot }\end{array}$} & \multicolumn{8}{|c|}{ Varijabla - Variable } \\
\hline & & $\mathrm{N}$ & Min. & Max. & Mean & Std. error & Variance & Std. Dev. & Median \\
\hline \multirow{8}{*}{$\begin{array}{l}\text { Hrast Lužnjak } \\
\text { Pedunculate oak }\end{array}$} & $\mathrm{A} 1$ & 92 & 39,0 & 185,0 & 85,9 & 3,2 & 951,3 & 30,8 & 80,0 \\
\hline & B3 & 40 & 30,0 & 180,0 & 83,6 & 5,9 & 1377,0 & 37,1 & 75,0 \\
\hline & $\mathrm{C} 2$ & 85 & 36,0 & 230,0 & 115,4 & 4,7 & 1902,5 & 43,6 & 110,0 \\
\hline & $\mathrm{C} 4$ & 37 & 30,0 & 210,0 & 112,3 & 6,6 & 1616,6 & 40,2 & 110,0 \\
\hline & D1 & 39 & 40,0 & 189,0 & 87,9 & 6,3 & 1524,6 & 39,0 & 70,0 \\
\hline & D4 & 77 & 35,0 & 190,0 & 98,0 & 3,9 & 1190,6 & 34,5 & 95,0 \\
\hline & F2 & 43 & 27,0 & 290,0 & 87,9 & 7,2 & 2220,6 & 47,1 & 73,0 \\
\hline & F3 & 91 & 40,0 & 200,0 & 95,6 & 3,6 & 1195,0 & 34,6 & 90,0 \\
\hline \multirow{8}{*}{$\begin{array}{l}\text { Poljski jasen } \\
\text { Narrow-leaved ash }\end{array}$} & A3 & 91 & 30,0 & 380,0 & 132,6 & 7,5 & 5079,8 & 71,3 & 115,0 \\
\hline & B1 & 90 & 24,0 & 277,0 & 94,2 & 4,8 & 2111,6 & 46,0 & 93,5 \\
\hline & B2 & 46 & 29,0 & 390,0 & 144,3 & 12,6 & 7281,3 & 85,3 & 139,5 \\
\hline & C3 & 46 & 50,0 & 220,0 & 107,2 & 5,8 & 1540,7 & 39,3 & 100,0 \\
\hline & E1 & 47 & 35,0 & 195,0 & 109,6 & 6,3 & 1890,2 & 43,5 & 101,0 \\
\hline & E2 & 94 & 32,0 & 195,0 & 100,7 & 3,6 & 1189,8 & 34,5 & 95,5 \\
\hline & E4 & 44 & 23,0 & 220,0 & 97,2 & 6,5 & 1846,2 & 43,0 & 87,5 \\
\hline & F4 & 86 & 30,0 & 200,0 & 102,5 & 4,2 & 1496,7 & 38,7 & 95,0 \\
\hline \multirow{4}{*}{$\begin{array}{l}\text { Obični bagrem } \\
\text { Black locust }\end{array}$} & A2 & 45 & 107,0 & 610,0 & 371,5 & 22,1 & 21968,0 & 148,2 & 365,0 \\
\hline & B4 & 50 & 90,0 & 495,0 & 357,6 & 13,1 & 8640,2 & 93,0 & 395,0 \\
\hline & C1 & 50 & 81,0 & 420,0 & 253,5 & 11,8 & 6973,5 & 83,5 & 234,0 \\
\hline & D3 & 50 & 200,0 & 580,0 & 403,1 & 12,1 & 7265,2 & 85,2 & 400,0 \\
\hline \multirow{8}{*}{$\begin{array}{l}\text { Divlja trešnja } \\
\text { Willd cherry }\end{array}$} & A4 & 7 & 40,0 & 174,0 & 122,7 & 16,3 & 1864,9 & 43,2 & 135,0 \\
\hline & B2 & 19 & 54,0 & 450,0 & 186,4 & 21,3 & 8625,9 & 92,9 & 195,0 \\
\hline & C3 & 10 & 60,0 & 170,0 & 113,0 & 12,5 & 1551,1 & 39,4 & 107,5 \\
\hline & D2 & 20 & 80,0 & 270,0 & 169,4 & 11,8 & 2784,7 & 52,8 & 165,0 \\
\hline & E1 & 17 & 30,0 & 250,0 & 154,7 & 14,1 & 3400,2 & 58,3 & 180,0 \\
\hline & E3 & 8 & 90,0 & 210,0 & 150,3 & 16,2 & 2096,2 & 45,8 & 167,5 \\
\hline & E4 & 8 & 100,0 & 240,0 & 180,0 & 14,6 & 1711,1 & 41,4 & 176,0 \\
\hline & F1 & 19 & 65,0 & 220,0 & 120,1 & 8,9 & 1515,3 & 38,9 & 120,0 \\
\hline \multirow{8}{*}{$\begin{array}{l}\text { Obični grab } \\
\text { Common hornbeam }\end{array}$} & A4 & 3 & 40,0 & 200,0 & 106,7 & 48,1 & 6933,3 & 83,3 & 80,0 \\
\hline & B3 & 14 & 45,0 & 130,0 & 80,4 & 8,2 & 940,2 & 30,7 & 70,0 \\
\hline & C4 & 9 & 50,0 & 200,0 & 97,4 & 16,5 & 2441,3 & 49,4 & 80,0 \\
\hline & D1 & 11 & 34,0 & 169,0 & 80,7 & 13,8 & 2084,2 & 45,7 & 65,0 \\
\hline & $\mathrm{D} 2$ & 20 & 55,0 & 210,0 & 129,9 & 9,7 & 1868,7 & 43,2 & 123,5 \\
\hline & E3 & 5 & 40,0 & 220,0 & 111,0 & 30,4 & 4630,0 & 68,0 & 90,0 \\
\hline & F1 & 22 & 81,0 & 220,0 & 131,1 & 9,4 & 1949,8 & 44,2 & 118,0 \\
\hline & F2 & 9 & 63,0 & 240,0 & 138,3 & 21,7 & 4228,5 & 65,0 & 132,0 \\
\hline
\end{tabular}


Tablica 7. Rezultati jednostruke analize varijance po vrstama drveća Table 7 Results of one-way analysis of variance per tree species

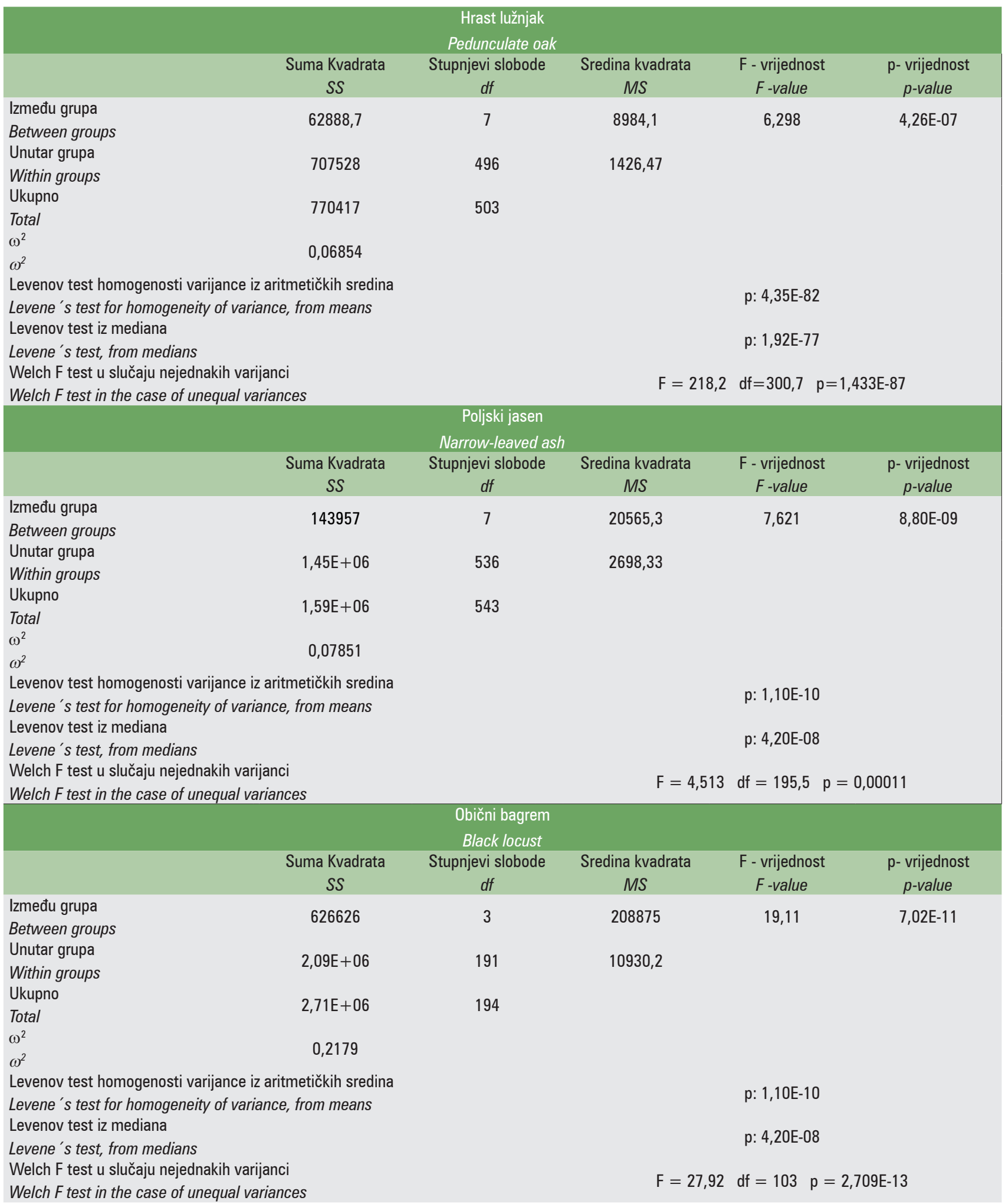

Za hrast lužnjak je utvrđeno da se plohice C2 i C4 statistički značajno razlikuju od plohica A1, D1, F2 i B3. Najveće visine u prosjeku ustanovljene na plohicama C2 i C4 koje su smještene u nizi. Niže visine na plohicama B3 i F2 možemo pripisati povišenom mikroreljefu i sušim uvjetima u tlu.
Poljski jasen pokazuje statistički značajne razlike između plohica A3 te B1, E2, E4 i F4. Plohica B2 statistički se značajno razlikuje od plohica C3, E1, E2, E4 i F4. Ta plohica ima veću vrijednost standardne devijacije, odnosno veću disperziju visina. Također, postoji značajna razlika između 
Tablica 8. Rezultati Tukey HSD post hoc testa $(p<0,05)$ po vrstama drveća Table 8 Results of Tukey HSD post hoc test $(p<0,05)$ per tree species

\begin{tabular}{|c|c|c|c|c|c|c|c|c|}
\hline \multicolumn{9}{|c|}{ Hrast lužnjak } \\
\hline $\begin{array}{l}\text { Plohica } \\
\text { Subplot }\end{array}$ & $\mathrm{A} 1$ & B3 & C2 & C4 & D1 & D4 & F2 & F3 \\
\hline A1 & & 1 & 1,23E-03 & $6,60 \mathrm{E}-03$ & 1 & 0,7088 & 1 & 0,8796 \\
\hline B3 & & & $3,27 \mathrm{E}-04$ & $1,93 \mathrm{E}-03$ & 0,9989 & 0,4908 & 0,9988 & 0,7082 \\
\hline C2 & & & & 0,9999 & 3,79E-03 & 0,2407 & $3,86 \mathrm{E}-03$ & 0,1165 \\
\hline C4 & & & & & $1,78 \mathrm{E}-02$ & 0,5005 & $1,80 \mathrm{E}-02$ & 0,2981 \\
\hline D1 & & & & & & 0,8634 & 1 & 0,9633 \\
\hline D4 & & & & & & & 0,8654 & 1 \\
\hline F2 & & & & & & & & 0,9641 \\
\hline F3 & & & & & & & & \\
\hline \multicolumn{9}{|c|}{ Poljski jasen } \\
\hline \multicolumn{9}{|c|}{ Narrow-leaved ash } \\
\hline $\begin{array}{l}\text { Plohica } \\
\text { Subplot }\end{array}$ & A3 & B1 & B2 & C3 & E1 & E2 & E4 & F4 \\
\hline A3 & & 1,19E-03 & 0,9198 & 0,1221 & 0,2211 & $1,62 \mathrm{E}-02$ & $4,33 \mathrm{E}-03$ & $3,03 \mathrm{E}-02$ \\
\hline B1 & & & $3,45 \mathrm{E}-05$ & 0,8675 & 0,7277 & 0,9972 & 1 & 0,9876 \\
\hline B2 & & & & $2,08 \mathrm{E}-03$ & $5,66 \mathrm{E}-03$ & $1,26 \mathrm{E}-04$ & $4,64 \mathrm{E}-05$ & 2,67E-04 \\
\hline C3 & & & & & 1 & 0,9974 & 0,9662 & 1 \\
\hline E1 & & & & & & 0,9816 & 0,8949 & 0,9997 \\
\hline E2 & & & & & & & 1 & 1 \\
\hline E4 & & & & & & & & 0,9993 \\
\hline \multicolumn{9}{|c|}{ Obični bagrem } \\
\hline \multicolumn{9}{|c|}{ Black locust } \\
\hline $\begin{array}{l}\text { Plohica } \\
\text { Subplot }\end{array}$ & $\mathrm{A} 2$ & B4 & C1 & D3 & & & & \\
\hline A2 & & 0,9141 & 7,84E-06 & 0,4428 & & & & \\
\hline B4 & & & $1,27 \mathrm{E}-05$ & 0,1389 & & & & \\
\hline $\mathrm{C1}$ & & & & $7,72 \mathrm{E}-06$ & & & & \\
\hline D3 & & & & & & & & \\
\hline
\end{tabular}

plohica B1 i B2. Prosječna visina i vrijednost standardne devijacije znatno je niža na plohici B1. Najniži prosjek visina od $82,3 \mathrm{~cm}$ ima plohica B1, koja se većim dijelom nalazi na gredi. Najviše prosjeke visina postigle su biljke na plohicama A3 i B2, koje se većim dijelom nalaze u nizi.

Kod bagrema su također utvrđene statistički značajne razlike, i to između plohica C1 i A2 te B4 i D3. Plohica C1 pokazuje najslabije rezultate, s prosječnom visinom od 253 $\mathrm{cm}$. Najbolje rezultate pokazuje plohica D3, koja se svojim većim dijelom nalazi u nizi. Plohica A2 je posebno zanimljiva, jer se rasprostire preko izražene mikroreljefne udubine i uzvisine. Na njoj su biljke bagrema ekstremno visoke, s prosječnom visinom od $443 \mathrm{~cm}$ (ukupno 30 biljaka u nizi), dok ostatak biljaka koji se nalazi na gredi ima prosječnu visinu od $228 \mathrm{~cm}$ (15 biljaka). Na plohici A2 mikroreljefna diferencijacija je posebno izražena, što se očituje i u vrijednosti standardne devijacije.

Kod divlje divlje trešnje nisu utvrđene statistički značajne razlike u visinama između pojedinih plohica. Iako plohica B2 pokazuje najvišu vrijednost prosječne visine biljaka od
$186,4 \mathrm{~cm}$, treba napomenuti da na taj prosjek utječe jedna biljka divlje trešnje visoka $450 \mathrm{~cm}$. Plohica D2 koja se nalazi $\mathrm{u}$ nizi pokazuje najbolje razultate.

Jednostrukom analizom varijance nije utvrđena statistički značajna razlika između pojedinih repeticija običnoga graba. Kao i kod divlje trešnje, primjećuje se nizak opseg statističkog skupa u svim repeticijama. Najviše vrijednosti prosječnih visina biljaka pokazuju plohice koje se većim dijelom nalaze u nizi (D2 i F1).

\section{RASPRAVA DISCUSSION}

Šumske kulture, intenzivne šumske kulture i šumske plantaže topola u našoj su se praksi osnivale umjetnom obnovom sadnicama nakon čiste sječe starih topolovih sastojina i pošumljavanjem sadnicama na neobraslim šumskim zemljištima. Tako su šumske kulture, prema Antunoviću (1995.), obično osnivane na manje kvalitetnim tlima rječnog poloja, između korita i nasipa, na staništima koja od 
prirode inače obrašta šumska zajednica crne i bijele topole (Populetum nigro-albae Slav. 1952). Intenzivne šumske kulture i šumske plantaže osnivale su se na najkvalitetnijim staništima nekadašnjih ritskih šuma (Matić i dr., 2005.), primjerice na najvišim staništima sa starijim i razvijenijim aluvijalnim tlima na kojima su rasle prirodne šume veza i poljskog jasena s hrastom lužnjakom (Fraxino-Ulmetum laevis Slav. 1952), (Rauš i Matić, 1987.).

Kada je riječ o istraživanom području, u Gospodarskoj osnovi G. j. Valpovačke podravske šume za razdoblje 1974. - 1983. godine, na stranici 8, u poglavlju Površina - komparacija sa stanjem 1967. godine, o postanku prve generacije nasada topola piše kako je "u površinu gospodarske jedinice uključeno novih 300,70 ha poljoprivrednih i pašnjačkih površina otkupljenih od privatnih posjednika, od kojih je najveći dio (predjel Topolje, op. aut.) već pošumljen EA (euroameričkim) topolama". U prethodnoj Gospodarskoj osnovi za razdoblje 1957. - 1966. godine te su površine na šumskogospodarskoj karti posebno označene uz opasku: "1961. - novo plantažiranje". Riječ je o odjelima koji se danas nalaze južno od nasipa, u dijelu branjenom od poplave, i nose oznake $16-29$. Oni su predmet naših istraživanja u šumskom predjelu Topolje. Na stranici 15 istog dokumenta, u poglavlju Način gospodarenja, za uređajni razred Plantaže EA topole ophodnje 20 godina, između ostaloga, piše: "Momentalno u okviru sadašnjih plantaža nalazimo mješavine tri klona EA topole i to 'I-214', 'Robusta' i 'Marilandica', ali izdvajanje ovih klonova na posebne odsjeke nije izvršeno, jer su međusobno izmješani u manjim grupama. Na ovim plantažnim razredima EA topole vrši se u ovisnosti od mogućnosti šumarije međuredna obrada zemljišta $1-2$ puta godišnje te formiranje vrhova stabala i 2 -3 orezivanja grana u periodu od 2. do 6. godine starosti plantaže. Obnovu plantaže treba i dalje vršiti isključivo sadnicama klonova EA topole 2/3 u 6-kutnoj sadnji”".

Može se zaključiti kako su te sastojine osnovane na obešumljenim i degradiranim tlima koja su prije toga obrađivana ili su korištena za ispašu. Zato je nasad topola imao svojstva pionirske šume. Uzgajanjem topola u nekoliko ophodnji na istom staništu dolazi do znakovitih stanišnih promjena koje uzrokuju njihovo slabije uspijevanje, što se može povezati s očekivanim prirodnim progresivnim sukcesijskim procesom prema trajnoj šumskoj zajednici (Matić i dr., 1996.). Na području donjeg dijela toka rijeke Drave to je šumska zajednica veza i poljskog jasena s hrastom lužnjakom (Fraxino-Ulmetum laevis Slavnić 1952), (Vukelić i Baričević 2004., 1999.). Njezinu morfologiju i strukturu opisali su Anić i dr. (2005.).

Za očekivati je da će se na staništima na kojima se topolovi nasadi uzgajaju, višekratno pojaviti potreba za zamjenom sastojinskog oblika. Nagle promjene u uspjehu uzgajanja šuma topola su sve češća pojava, a prema Sikori (1996.), posljedica su sljedećih čimbenika: biološki zamor klona, širenje nasada na nove površine koje su inače manje podesne za tu namjenu, poremećen režim podzemnih i poplavnih voda te pojava niza sušnih godina s nepovoljnim rasporedom oborina, posebice u doba vegetacije. O neuspjeloj obnovi nasada topola na vukovarskim adama i ritovima krajem 20. stoljeća izvješćuju Mayer (1999.) te Mayer i Hećimović (2008.). Navodi se da je unatoč dubokoj sadnji i kvalitetnim sadnicama uspjeh iz godine u godinu sve lošiji. Uzroke toj pojavi se povezuje s pjeskovitim tlom, ekstenzivnim načinom uzgajanja te promjenama u staništu.

Istraživanja Anića i dr. (2008., 2010., 2013.) ustanovila su negativne promjene uvjeta uspijevanja topola na istraživanom području uz rijeku Dravu kod Osijeka: nedostatan sadržaj vode u tlu koji je posljedica smanjenja količine oborine i izostanka redovitih poplava, slabe uvjete ishrane topola koji proizilaze iz rezultata biljnohranidbenih analiza i analiza opskrbljenosti tla biogenim elementima, opadanje vitalnosti topola i pojava biljnih bolesti kao što je Phytophtora cambivora (Petri) Buisman, korištenje neadekvatnih klonova topola na specifičnim staništima, uzgajanje topole u trećoj ophodnji na istim staništima te ekstenzivan pristup i smanjenje intenziteta šumskouzgojnih radova.

S gledišta uzgajanja šuma problem se može sagledati na dva načina (Anić i Kajba, 2015.):

1) Ako nema progresivnih stanišnih promjena, a vodni režim i biljnohranidbeni status tala to omogućuju, treba nastaviti uzgajanje topola na način koji je dobro poznat šumarskim praktičarima. Multiklonski pristup pri osnivanju nasada i uvođenje novih klonova u proizvodnju, uz intenziviranje radova njege, u tom će slučaju značajno doprinijeti uspjehu u podizanju produktivnih i stabilnih nasada.

2) U uvjetima promijenjenih stanišnih prilika potrebno je pristupiti zamjeni ili supstituciji sastojinskog oblika. To znači umjesto topole uzgajati druge vrste drveća koje u promijenjenim stanišnim prilikama mogu uspijevati.

Zamjena sastojinskog oblika koja se obavlja u skladu s ostvarenom progresivnom sukcesijom u prirodnom uzgajanju šuma podrazumijeva umjetnu obnovu autohtonim vrstama drveća trajne šumske zajednice. Postupak je bolje obaviti pod zastorom krošanja, po mogućnosti na malim površinama, uz detaljno šumskouzgojno planiranje. Ovo je istraživanje pokazalo mogućnost uporabe za tu namjenu poljskog jasena i hrasta lužnjaka kao temeljnih vrsta drveća trajne šumske zajednice. Uz obični bagrem, te dvije vrste pokazale su najbolje rezultate tijekom praćenja pokusa. $\mathrm{Na}$ poljskom jasenu u pokusu nisu zabilježeni znakovi zaraze novom bolešću. Negativni nalazi na osječkom području potvrđeni su 2011. i 2015. godine (Diminić, 2015., Milotić, 2017.). Poljski jasen je najbolje reagirao na čepovanje, nakon mraza koji se dogodio u proljeće 2012. godine. 
Poseban su problem ona staništa gdje je tlo naglo ostalo suho, bez podzemne i poplavne vode. Riječ je o specifičnim slučajevima fluvisola u regresiji s pjeskovitom podlogom. Čini se kako će na takvim tlima trebati nastaviti uzgajati pionirske vrste drveća, i to one koje su im po svojim ekološkim zahtjevima i biološkim svojstvima bolje prilagođene od topola. Ovo je istraživanje pokazalo kako je za tu namjenu najbolje uporabiti obični bagrem.

Sve to ne znači odustajanje od uzgajanja topola. Nove nasade treba osnivati ponovno ako se promjene u značajkama staništa nisu dogodile ili u slučaju pošumljavanja neobraslih proizvodnih šumskih zemljišta, sve uz uvjet povoljnog vodnog režima tala. Posebnu pozornost prilikom analize staništa i donošenja odluke o nastavku uzgajanja topola treba posvetiti u slučaju kada bi se nasad trebao osnovati u trećoj ili višoj ophodnji. Prilikom osnivanja i njege nasada potrebno je dosljedno obavljati sve postupke koje je šumarska praksa na području Osijeka do sada uspješno upotrebljavala, od proizvodnje kvalitetnih sadnica, preko uvida u profil tla i same sadnje do njege nasada. Racionalizacija šumskouzgojnih radova kratkoročno može polučiti financijske uštede, ali dugoročno vodi problemima u uspijevanju sastojina i kasnijim većim financijskim izdacima u saniranje stanja.

U svakom slučaju, potrebno je napustiti ekstenzivan pristup uzgajanju šuma u novonastalim uvjetima. To znači intenzivirati šumskouzgojne radove, smanjiti radne površine i izlučivati nove odsjeke, za svaki od njih izrađivati šumskouzgojni plan, pojačati kontrolu i odgovornost prilikom planiranja i izvođenja radova (Anić i dr., 2008.).

\section{ZAKLJUČAK}

\section{CONCLUSION}

Rezultati istraživanja pokazali su kako je nasade topola u promijenjenim stanišnim prilikama nakon višekratnih ophodnji moguće zamijeniti sa sastojinom koja svojim sastojinskim oblikom odgovara terminalnoj šumskoj zajednici istraživanoga podučja - veza i poljskog jasena s hrastom lužnjakom (Fraxino-Ulmetum laevis Slavnić 1952).

Postupak traži intenzivni stručni pristup. Prethodi mu izrada detaljnog šumskouzgojnog plana koji bi, između ostalog, definirao područja niza i greda u nekom odjelu. Nize i vlažne grede treba prepustiti poljskom jasenu koji je pokazao vrlo dobre rezultate u ovome pokusu. Hrast lužnjak je pokazao zavidnu stabilnost i vitalitet, pa ga treba upotrebljavati u smjesi s poljskim jasenom. Obični bagrem preporuča se za najsuše lokalitete s pjeskovitim tlima koja su naglo ostala bez podzemne i poplavne vode, na kojima nema uvjeta za nastavak uzgajanja topola.

S obzirom na preživljenje i visine kao indikatore rasta i razvoja biljaka, najbolje su rezultate pokazali redom obični bagrem, poljski jasen i hrast lužnjak. Najlošije rezultate postigli su divlja trešnja i obični grab.

Najbolje preživljenje nakon pet vegetacija utvrđeno je za obični bagrem $97,50 \%$, poljski jasen $90,88 \%$ i hrast lužnjak $82,88 \%$. Slijede divlja trešnja, čije je petogodišnje preživljenje $54,00 \%$ i obični grab s preživljenjem od $23,25 \%$. Preživljenje bagrema je na visokoj razini kroz čitavo petogodišnje razdoblje. Preživljenje hrasta lužnjaka je na vrlo dobroj razini, ali s trendom opadanja tijekom prve četiri godine praćenja. Obrnuti trend ima poljski jasen kojemu je preživljenje, nakon obavljenog čepovanja, naglo poraslo i sada je na vrlo dobroj razini. Najveći pad preživljenja zabilježen je kod divlje trešnje i običnoga graba.

S obzirom na mikroreljef, najbolje preživljenje je pokazao obični bagrem koji podjednako dobro raste u nizi i na gredi. Poljski jasen i hrast lužnjak bolje preživljenje imaju u nizi. Divlja trešnja i obični grab imaju općenito loše preživljenje, neovisno o mikroreljefu.

Utvrđena je statistički značajna razlika u visinama između ispitivanih vrsta, osim između hrasta lužnjaka i poljskog jasena, hrasta lužnjaka i običnog graba te između poljskog jasena i običnog graba. Prosječna visina hrasta lužnjaka nakon pet vegetacija iznosi $96,5 \mathrm{~cm}$, običnog graba $112,8 \mathrm{~cm}$, poljskog jasena $110,0 \mathrm{~cm}$, divlje trešnje $152,5 \mathrm{~cm}$, a bagrema $345,8 \mathrm{~cm}$.

Analizom visina biljaka između plohica unutar pojedine vrste drveća, ustanovljena je statistički značajna razlika kod hrasta lužnjaka, poljskog jasena i bagrema, dok kod divlje trešnje i običnoga graba nije bilo razlika. U većini slučajeva ta razlika je utvrđena za plohice koje se nalaze u nizi. To se može povezati s povoljnijim uvjetima vlaženja.

\section{ZAHVALA}

\section{ACKNOWLEDGEMENT}

Istraživanje je obavljeno u sklopu projekta Mogućnost obnove nasada topola nakon višekratnih ophodnji, koje su financirale Hrvatske šume d.o.o. Zagreb, u nekoliko faza tijekom razdoblja 2006. - 2013. godine. Posebno se zahvaljujemo na pomoći kolegama i suradnicima iz Uprave šuma podružnica Osijek, Šumarije Valpovo i Šumarije Osijek.

\section{LITERATURA}

\section{REFERENCES}

- Anić, I., D. Kajba, 2015: Mogućnost obnove nasada topola uz rijeku Dravu kod Osijeka. U: S. Matić, F. Tomić, I. Anić (ur.), Zbornik radova sa znanstvenog skupa Proizvodnja hrane i šumarstvo - temelj razvoja istočne Hrvatske. Hrvatska akademija znanosti i umjetnosti, Zagreb, 255 - 269.

- Anić, I. (ur.), 2013: Mogućnost obnove nasada topola nakon višekratnih ophodnji - završno izvješće. Elaborat, završno izvješće projekta za razdoblje 2011. - 2013., Šumarski fakultet Sveučilišta u Zagrebu, 70 str., Zagreb. 
- Anić, I., D. Kajba, N. Potočić, I. Pilaš, 2010: Mogućnost obnove nasada topola nakon višekratnih ophodnji - faza II. Elaborat, završno izvješće projekta za razdoblje 2009. - 2010., Šumarski fakultet Sveučilišta u Zagrebu, Zagreb, 68 str.

- Anić, I., D. Kajba, N. Potočić, I. Pilaš, M. Županić, 2008: Mogućnost obnove nasada topola nakon višekratnih ophodnji. Elaborat, završno izvješće projekta za razdoblje 2006. - 2008., Šumarski fakultet Sveučilišta u Zagrebu, Zagreb, 82 str.

- Anić, I., S. Matić, M. Oršanić, B. Belčić, 2005: Morfologija i struktura šuma poplavnih područja. U: J. Vukelić (gl. ur.), Poplavne šume u Hrvatskoj, Akademija šumarskih znanosti, Zagreb, $245-262$.

- Antunović, S., 1995: Tehnologija podizanje plantaža i intenzivnih kultura topola i vrba. Prilozi raspravi o biološkoj reprodukciji šuma topola i vrba, Ministarstvo poljoprivrede i šumarstva Republike Hrvatske, Hrvatska komisija za topolu, Zagreb, str. 1 - 5.

- Dekanić, I., 1979: Uzgojne mjere i proizvodnja u nekim prirodnim sastojinama i kulturama euroameričkih topola slavonskog područja. Šumarski list 103(7 - 8): 299 - 332.

- Diminić, D., 2015: Nova bolest jasena (Fraxinus spp.) u Hrvatskoj. U: S. Matić, F. Tomić, I. Anić (ur.), Zbornik radova sa znanstvenog skupa Proizvodnja hrane i šumarstvo - temelj razvoja istočne Hrvatske. Hrvatska akademija znanosti i umjetnosti, Zagreb, 363 - 373.

- Hammer, Ø., D. A. T. Harper, P. D. Ryan, 2001: PAST: Paleontological statistics software package for education and data analysis. Palaeontologia Electronica 4(1): 9pp. http://palaeo-electronica.org/2001_1/past/issue1_01.htm

- Hrvatsko povjerenstvo za topolu, 2015: Izvješće za razdoblje 2012. - 2015., Ministarstvo poljoprivrede Republike Hrvatske, Hrvatsko povjerenstvo za topolu, Zagreb 18 str.

- Matić, S., M. Oršanić, I. Anić, 2005: Osnivanje šumskih kultura i plantaža glavnih vrsta drveća poplavnih šuma. U: J. Vukelić (gl. ur.), Poplavne šume u Hrvatskoj, Akademija šumarskih znanosti, Zagreb, 297 - 307.

- Matić, S., M. Oršanić, I. Anić, 1996: Prirodne sastojine topola i vrba u današnjim ekološkim i gospodarskim uvjetima Hrvatske. U: Mayer, B. (ur.), Unapređenje proizvodnje biomase šumskih ekosustava, Šumarski fakultet Sveučilišta u Zagrebu i Šumarski institut, Jastrebarsko, Zagreb, 217 - 228.
- Mayer, Ž., Ž. Hećimović, 2008: Obnova ritskih šuma hrvatskog podunavlja uz oplemenjivanje sadnicama poljskog jasena (Fraxinus angustifolia Vahl). Šumarski list 132(1 - 2): 43 - 52.

- Mayer, Ž., 1999: Ritske šume hrvatskog Podunavlja i njihova prirodna obnova. Glasnik za šumske pokuse 31: 391 - 434.

- Milotić, M., 2017: Uloga gliive Hymenoscyphus fraxineus (T. Kowalski) Baral, Queloz \& Hosoya u odumiranju jasena (Fraxinus spp.) u Republici Hrvatskoj. Doktorska disertacija, Sveučilište u Zagrebu Šumarski fakultet, 1 - 274 str.

- Osnove gospodarenja G. j. Osječke podravske šume za razdoblja: 1967.-1976., 1977.-1986., 1987.-1996., 1997.-2006., 2007.-2016., Hrvatske šume, d.o.o. Zagreb, Uprava šuma podružnica Osijek.

- Osnove gospodarenja G. j. Valpovačke podravske šume za razdoblja: 1957.-1966., 1967.-1977., 1974.-1983., 1984.-1993., 1994.-2003., 2004.-2013., Hrvatske šume, d.o.o. Zagreb, Uprava šuma podružnica Osijek.

- Podhorski, I., 1951: Uzgoj topola. Poljoprivredni nakladni zavod, Zagreb, 65 str.

- Rauš, Đ., S. Matić, 1987: Ritske šume. Šumarska enciklopedija, JLZ Miroslav Krleža, Zagreb, 155 - 159.

- Sikora, J., 1996: Primjena duboke sadnje. Šumarski list 120(56): 235-241.

- Sikora, J., 1995: Općenito o šumama poplavnog područja s posebnim osvrtom na prirodne šume. Prilozi raspravi o biološkoj reprodukciji šuma topola i vrba, Hrvatska komisija za topolu, Kondrić.

- Španović, T., 1931: Meke ili ritske šume u Podunavlju. Šumarski list 55(3): $92-123$.

- Tukey, J., 1949: Comparing Individual Means in the Analysis of Variance. Biometrics, 5(2): 99 - 114.

- Vukelić, J., D. Baričeić, 2004: The association of spreading elm and narrow-leaved ash (Fraxino-Ulmetum laevis Slav. 1952) in floodplain forests of Podravina and Podunavlje. Haequetia 3(1): $49-60$.

- Vukelić, J., D. Baričević, Z. Perković, 1999: Vegetacijske i druge značajke zaštićenog dijela "Slatinskih podravskih šuma". Šumarski list, 123(7 - 8): 287 - 299.

- Welch, B. L. 1951: On the Comparison of Several Mean Values: An Alternative Approach. Biometrika, 38: 330 - 336, doi: $10.2307 / 2332579$.

\section{Summary}

The paper presents the results of research on the survival and growth of several tree species which could be used to replace poplars in plantations if necessary. The experiment was established in the area of Valpovo Forest Office, in the Management Unit of Valpovačke Podravske Šume, forest area of Topolje, sub-compartment 23a. This locality is a typical example of poor growth and dieback of poplar plantations even after multiple restocking with poplar seedlings and tending. The experiment was set up according to the randomized block design, with six treatments in four blocks. The following stand forms were treated: A - pedunculate oak, B - narrow-leaved ash, C - black locust, D - pedunculate oak with common hornbeam, E - wild cherry with narrow-leaved ash, and F - wild cherry with common hornbeam. The experiment was established on November 18, 2000. Plant survival was recorded every year over a five-year trial monitoring period. During the winter of 2015, the height of all the trees was measured and the spatial position of live and dead individuals per subplot was determined. In terms of survival and height as indicators of plant growth and development, the best results were manifested by black locust, followed by narrow-leaved ash and pedunculate oak. The poorest re- 
sults were achieved by wild cherry and common hornbeam. With regard to the micro-relief, the best survival was displayed by black locust, which grows equally well both in unsoaked micro depressions (niza) and on micro elevations (greda). Narrow-leaved ash and pedunculate oak survived better in micro-depressions. In general, wild cherry and common hornbeam showed poor survival irrespectively of the micro-relief. Research results confirm the hypothesis regarding the need to replace or substitute poplar plantations under changed site conditions towards a stand whose stand form is adequately suited to the terminal forest community of the study area - spreading elm and narrow-leaved ash with pedunculate oak (Fraxino-Ulmetum laevis Slavnić 1952). The procedure should be preceded by a detailed forest management plan which would, among other things, define the areas of microdepressions and micro-elevations in a particular compartment. Micro-depressions and wet micro-elevations should be reserved for narrow-leaved ash, which showed very good results in the trial. Pedunculate oak displayed very good stability and vitality and should therefore be used in a mixture with narrow-leaved ash. Black locust proved to be suitable in all conditions, but it is recommended to use it over the driest and sandy soils which have abruptly remained without ground and floodwater.

KEY WORDS: poplars, pedunculate oak, narrow-leaved ash, black locust, analysis of variance 